\title{
О ЗНАЧИМОСТИ И ВОСПИТАТЕЛЬНЫХ ВОЗМОЖНОСТЯХ ДИСЦИПЛИНЫ «ИСТОРИЯ ИСКУССТВА» ДЛЯ СТУДЕНТОВ ХУДОЖЕСТВЕННОЙ АКАДЕМИИ
}

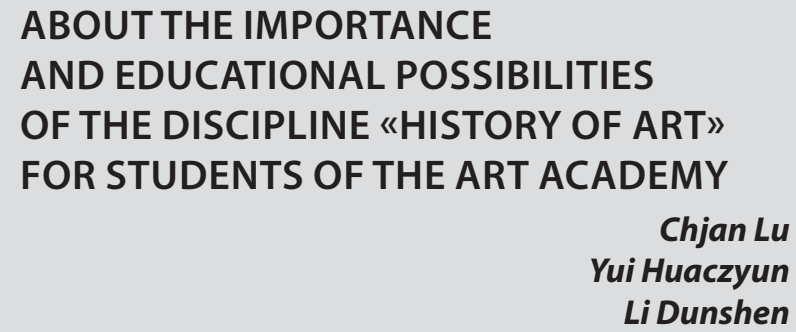

ABOUT THE IMPORTANCE AND EDUCATIONAL POSSIBILITIES OF THE DISCIPLINE «HISTORY OF ART» FOR STUDENTS OF THE ART ACADEMY Chjan Lu Yui Huaczyun Li Dunshen

Summary:The article presents the results of the analysis of the significance and educational possibilities of such a discipline as «History of Art» within the framework of its teaching for students of the Art Academy. Also, the paper gives a characteristic of the educational program of the discipline, considers its distinctive features, features and advantages, the potential for educating young people. The article highlights the issues of artistic education and education, which contribute to the spiritual development of a modern person, which is especially important in the 21st century, taking into account today's challenges and realities. Referring to the past experience in the course of classes in the discipline "History of Art» and its analysis in a modern context allows you to better understand important topics, eliminate the existing «blank spots» in the knowledge of a particular direction being studied.

Keywords: history of art, art education, art education, educational program.
Чжан Лу

Преподаватель, Хэбэйская академия искусств; сотрудник по иностранным делам, Международный Центр обменов и сотрудничества, г. Шицзячжуань, провинция Хэбэй, КНР

794150053@q9.com

Юй Хуацзюнь

член Ассочиации художников провинции Ляонин, преподаватель, Даляньская академия искусств, г. Далянь, провинция Ляонин, КНР 13940868887@163.com

Ли Дуншэн

дочент, Даляньская академия искусств, г. Далянь, провинция Ляонин, КНР 455821356@qq.com

Аннотация: В статье приводятся результаты выполненного анализа значимости и воспитательных возможностей такой дисциплины как «История искусства» в рамках ее преподавания для студентов художественной академии. Также в работе дана характеристика образовательной программы дисциплины, рассмотрены ее отличительные черты, особенности и преимущества, потенциал для воспитания молодежи. Освещены вопросы художественного воспитания и образования, которые способствуют духовному развитию современного человека, что особенно актуально в XXI веке с учетом сегодняшних вызовов и реалий. Обращение к прошлому опыту в ходе занятий по дисциплине «История искусства» и его анализ в современном контексте позволяет лучше разобраться в важных темах, устранить имеющиеся «белы пятна» в познании того или иного изучаемого направления.

Ключевые слова: история искусств, художественное воспитание, художественное образование, образовательная программа.

собствуют духовному развитию человека, что во время информационной эпохи имеет особую важность. Образование и воспитание студентов посредством искусства сегодня является «общеевропейской идеей XXI века» [1]. Ведущей причиной формирования данной концепции и роста интереса к педагогическому обеспечению воспитательных возможностей дисциплин художественного профиля является форсированное развитие техногенного общества [2].

Для удовлетворения возрастающей потребности населения в «прекрасном» и противостояния засилью масскультуры, необходимо постоянно расширять и укреплять «плацдарм» духовных достижений посредством актуализации восприятия художественных произведений с учетом текущей реальности в первую очередь у студентов художественных академий, а также у обучающихся образовательных учреждений всех уровней раз- 
личных профилей. Для реализации поставленной цели необходим поиск новых эффективных подходов и методов, при этом полезным является обращение к прошлому опыту, истории [3].

Важно учитывать, что в нынешнем мире активными темпами протекают многочисленные изменения, которые называются вызовами, природа происхождения которых является сложной и многогранной. В преимущественном количестве случаев вызовы обусловлены необратимым и непредсказуемым развитием ряда глобальных процессов, в частности технократических, цивилизационных, социальных и природных. Стремительная глобализация перемещает в ранг стратегически важных государственных задач консолидацию людей с осознанием своей идентичности, признанием ценностей. Если говорить о Российской Федерации, важной задачей на данный момент является воспитание общероссийской гражданской идентичности среди молодежи, что становится возможным посредством комплексного воздействия в целом и изучения дисциплины «История искусств» в частности. Вызовы для современного общества обладают следующими характеристиками:

1. «Вымывание» истинных духовных ценностей посредством пропаганды коммерческой массовой культуры.

2. Низкий уровень гражданственности, долга и ответственности у представителей молодого поколения.

3. Отсутствие целевых регулярно проводимых прикладных и фундаментальных исследований, направленных на изучение истории идентичного искусства.

4. Вытеснение прошлых художественных образцов современным искусством.

5. Эпатажность как основа и главная тенденция для современных перформансов, сценических и театральных постановок, мероприятий и прочих событий.

6. Низкая популяризаций исторических культурных и художественных ценностей.

7. Стихийность протекающих активными темпами международных миграционных процессов.

8. Сокращение объема и снижение уровня межнациональных культурных обменов и контактов.

В последние годы была проведена масштабная работа, направленная на изучение и осознание этих проблем, что привело к старту реализации совокупности мер, ориентированных на сокращение глобальных разрывов с целью успешного развития Российской Федерации. Данные намерения и основные векторы были закреплены рядом государственных нормативно-правовых актов:

1. Стратегией гос. национальной политики РФ до 2025 г.

2. Национальным проектом «Культура» в совокупно- сти с другими проектами, которые входят в него, рассчитанным на 5 лет, с 2019 по 2024 года.

3. Основами гос. молодежной политики РФ до 2025 г.

4. Стратегией гос. культурной политики РФ до 2030 г. $[4,5,6,7]$.

Перечисленные, а также ряд других законодательных актов содержат аналитическое описание наблюдаемых проблем в области воспитания духовно-нравственных ценностей населения РФ, экспертные рекомендации для корректной организации работы в данном направлении и ключевые понятия.

Обобщение выполненного анализа перечисленных документов, которые задают главные векторы развития российского общества, выявило следующую тенденцию: воспитание молодежи, развитие их идентичности и духовно-нравственных ценностей посредством изучения истории искусства, рассмотрения достижений культуры, обучение народным художественным промыслам является необходимостью. История искусства при этом является эффективным ресурсом для формирования и развития национальной и культурной самореализации, самоидентификации.

Если говорить о педагогических обеспечении воспитательных возможностей дисциплины «История искусств» для студентов художественной академии, необходимо определить ее отличительные особенности как уникальной образовательной системы академии с присущим органическим единством компонентов:

1. Реализация требований ФГОС (Федеральных государственных образовательных стандартов).

2. Образовательная программа составлена на базе ФГОС соответствующего профиля.

3. Знакомство с богатым материальным и духовным наследием культуры, как отечественной, так и зарубежной; рассмотрение методик и характеристик мастерства их выполнения.

4. Реализация непрерывного образования.

5. Опора на творческую и художественную индивидуальность педагогов-мастеров как ценный ресурс совершенствования дисциплина.

6. Учет индивидуальных и художественных предпочтений, интересов и способностей обучающихся.

Все элементы и характеристики переплеты друг с другом, образуя единую эффективную систему преподавания дисциплины «История искусства», что открывает широкие возможности для реализации воспитательных возможностей в условиях художественной академии.

Необходимо отметить, что, говоря об особенностях дисциплины «История искусств», опирающейся на стандарты в процессе разработки учебной программы, выполняется формирование «триединства», которое раз- 
работано и представлено А.Г. Асмоловым:

1. Гражданская идентичность, выражающаяся посредством гражданской социализации и самосознания.

2. Этнокультурная идентичность, подразумевающей соединение человека со своей «малой родиной» и изготовление художественных изделий с учетом знаний об истории происхождения ремесел, соблюдения традиций национальной и региональной культуры.

3. Общечеловеческая идентичность, выражающаяся приобщением к произведениям мировой культуры и гуманистическим ценностям, которые разделяются всем миром [8].

Реализация «триединства» в ходе процесса обучения становится возможной за счет интегрированного подхода к составлению содержания учебных программ, что позволяет реализовывать данные принципы неделимо и целостно.

Интегрированный подход дисциплины «История искусств» позволяет сформировать у студентов художественной академии представление об истоках искусства и его развитии не только на территории своей страны, но также в других государствах на базе исторической, народной, этнической, бытовой и других составляющих иерархии ценностей как отдельного народа, так и всего человечества в целом [9].

Дисциплина нацеливает на это, так как в ее содержании центральное место занимает рассмотрение истории и теории искусства человеческой цивилизации, анализ наиболее выдающихся шедевров материальной культуры, начиная с древних времен и заканчивая се- годняшним днем, анализ художественной культуры существовавших и существующих этносов, рассмотрение национальных и региональных особенностей художественных промыслов.

\section{Зак^ючение}

Образовательная программа дисциплины «История искусств» открывает широкие воспитательные возможности доля работы со студентами художественной академии. В частности, она позволяет воспитывать:

1. Гражданскую идентичность.

2. Культуру межнационального общения.

3. Общечеловеческие гуманистические, эстетические, этические и нравственные ценности.

4. Культуру национального достоинства.

Учебная программа нацелена на осознание студентами принадлежности к общности со сформированным бытием и индивидуальностью; на погружение и приобщение к культурному мировому пространству; на обучение воспроизведения технологии изготовления материальных объектов ремесел и промыслов, воспроизведения культурных традиций.

Нормативное и методическое обеспечение дисциплины ориентировано на системную и последовательно выстроенную работу, главной цель которой является привитие студентам художественной академии культуры межнационального общения, уважения истории, сохранения и развития имеющегося наследия. Дополнительным ресурсом для расширения воспитательных возможностей дисциплины является расширение содержания и границ научной и исследовательской деятельности, а также проектной деятельности студентов.

\section{ЛИТЕРАТУРА}

1. Алексеева Л.Л. Исследования в области художественного образования в контексте реформирования отечественной науки // Педагогика искусства. 2015. № 1. С. 1-5.2.

2. Бычков В.В. Эстетика: учебник. 2-е изд., перераб. и доп. Москва, Гардарики, 2006. 573 с.

3. Мариупольская Т.Г. К вопросу о взаимосвязи традиций и новаторства в педагогике искусства [Электрон. ресурс] // Педагогика искусства. 2015 . №4. C. 6-9. Режим доступа: http://www.art-education.ru/sites/default/files/journal_pdf/mariupolskaya_6-9.pdf.

4. Указ Президента РФ от 19 декабря 2012 г. N 1666 «0 Стратегии государственной национальной политики Российской Федерации на период до 2025 года» (с изменениями и дополнениями)

5. Паспорт национального проекта «Культура» (утв. президиумом Совета при Президенте РФ по стратегическому развитию и национальным проектам, протокол от 24.12.2018 №16.

6. Распоряжение Правительства РФ от 29 ноября 2014 г. № 2403-р «06 утверждении Основ государственной молодежной политики РФ на период до 2025 г.»

7. Распоряжение Правительства РФ от 29.02.2016 № 326-р (ред. от 30.03.2018) «0б утверждении Стратегии государственной культурной политики на период до 2030 года»

8. Асмолов А.Г. Социальные эффекты образовательной политики // Национальный психологический журнал. - 2010. № 2 (4). С.100-106.

9. История художественного образования в России - проблемы культуры XX века. Москва: РАО, 2003. 412 с.

$$
\begin{gathered}
\text { ○ Чжан Лу (794150053@qq.сот), Юй Хуацзюнь (13940868887@163.com), } \\
\text { Ли Дуншэн (455821356@qq.сот). } \\
\text { Журнал «Современная наука: актуальные проблемы теории и практики» }
\end{gathered}
$$

